Cinémas

Revue d'études cinématographiques

Journal of Film Studies

\title{
Descriptive and Normative Norms in Film Adaptation: The Hays Office and the American Film Noir
}

\section{Patrick Cattrysse}

Volume 6, numéro 2-3, printemps 1996

URI : https://id.erudit.org/iderudit/1000978ar

DOI : https://doi.org/10.7202/1000978ar

Aller au sommaire du numéro

Éditeur(s)

Cinémas

ISSN

1181-6945 (imprimé)

1705-6500 (numérique)

Découvrir la revue

Citer cet article

Cattrysse, P. (1996). Descriptive and Normative Norms in Film Adaptation: The Hays Office and the American Film Noir. Cinémas, 6(2-3), 167-188.

https://doi.org/10.7202/1000978ar
Résumé de l'article

Cette étude sur les règles normatives et descriptives de l'adaptation dans le film noir américain échange l'habituelle analyse textuelle pour une analyse intersystémique du processus d'adaptation. Évitant ainsi d'aboutir à l'évaluation du niveau de fidélité du film à l'égard du roman, il devient possible d'examiner en quoi certaines normes sociales et certains modèles narratifs vont déterminer le passage de l'écrit à l'écran. 


\title{
Descriptive and Normative Norms in Film Adaptation : the Hays Office and the American Film Noir
}

\section{Patrick Cattrysse}

\begin{abstract}
RÉSUMÉ
Cette étude sur les règles normatives et descriptives de l'adaptation dans le film noir américain échange l'habituelle analyse textuelle pour une analyse intersystémique du processus d'adaptation. Évitant ainsi d'aboutir à l'évaluation du niveau de fidélité du film à l'égard du roman, il devient possible d'examiner en quoi certaines normes sociales et certains modèles narratifs vont déterminer le passage de l'écrit à l'écran.

\section{ABSTRACT}

The study of the normative and descriptive rules of adaptation in the American film noir replaces the usual textual analysis with an intersystemic analysis of the process of adaptation. Avoiding in this way an evaluation of the accuracy of the film with respect to the novel makes it possible to examine how certain social norms and certain narrative models will determine the passage from the written text to the screen.
\end{abstract}

The dominant discourse on film adaptation remains source text oriented and normative. It remains source text oriented because film adaptation is mainly or exclusively considered in relation with one source text. Discourse on film adaptation remains 
largely normative in the sense that an aesthetic or cultural value is attached to the film adaptation on the basis of its faithful reproduction of the source text. A so-called "poly-system" (PS) or "functional" approach offers a descriptive alternative. The approach is functional in the sense that it examines the functioning of one or more film adaptations in a particular historical context. Instead of prescribing how film adaptations should proceed, a functional approach tries to describe how one or more film adaptations have been produced and perceived in a particular historical context. Eventually it tries to explain why these film adaptations have functioned the way they have. Concepts like norms and models are crucial in this approach. The focus does not longer remain on the adequate reconstruction of one source text. Instead, the adaptation process is seen as determined by a complex set of models which have functioned simultaneously at different levels. Films translate parts of the story of a novel, but at the same time, they adapt previous conventions on the levels of music, mise en scène, photography, acting style, etc. By studying all kinds of modelling (source) material simultaneously, one is able to perceive the relative importance of each type of modelling material.

\section{Normative and descriptive norms}

Norms are defined as "energetic mechanisms which determine semiotic devices in a non-idiosyncratic way. " In my study on film noir adaptation (Cattrysse, 1992b), I mention several adaptation norms which seem to have determined the production process of the American film noir in the 1940's and 1950's in a more or less system(at)ic way. Examples of adaptation norms are the narrative pertinence versus redundancy, the straightforward narrative line and the suspense. These norms are "descriptive norms." They refer to actual adaptation behaviour. Descriptive norms are to be distinguished from normative norms which refer to behaviour which is desirable, but therefore not actually realised. The point I want to make here is that, although descriptive norms differ from normative ones, the study of the latter can be revealing in a descriptive approach such as the PS approach. It may be interesting to examine in what way 
and to what extent the normative norms have determined the actual adaptation behaviour, and thus become descriptive adaptation norms.

To illustrate this, I present a brief description of the workings of the Hays Office from its beginnings till the 1940's and the 1950's in the United States of America. I then pass on to some of its effects on the American film noir adaptation of that same period.

\section{Origins of The Hays Office}

One of the main systems of censorship in the Classical Hollywood cinema resided in the Production Code Administration (PCA). The PCA was developed out of the Motion Pictures Producers and Distributors (MPPDA), later called the Motion Picture Association of America (MPAA). The origins of the Production Code go back as far as the early 1920's, when William Harrison Hays, president of the MPPDA, proposed a formula, — " the" Formula —, which was elaborated in 1927 into a series of "Don'ts and Be Carefuls." This list of prohibitions and subjects-to-be-avoided or treated-with-caution referred mostly to sex and nudity. Some other rules dealt with violence, religion, racism, drugs and national feelings. The "Formula" was not enforced, however. Producers continued to make pictures as if the Formula did not exist.

Towards the end of the 1920's, the coming of sound brought about a new wave of "realism" in motion picture production, and infuriated reactions from Jewish as well as Catholic and Protestant communities intensified. It is at this point that, at the call of Hays, Martin Quigley, a Catholic layman, and Daniel F. Lord, a Jesuit professor of dramatics at the University of St. Louis, developed a Code from the list of "Don'ts and Be Carefuls." Unlike the previous attempts, Quigley and Lord tried to provide not only rules, but also reasons which might enable producers to give the rules more intelligent and broader application. The Code was officially accepted by the directors of the MPPDA on March 31, 1930, but it still remained a constitution without enforcement. Producers of movies continued to ignore the Code largely, and motion picture production of 1930 
until 1933 does hardly show any changes under the influence of the Production Code. It is only from 1934 onwards that a renewed threat of external censorship, coming from the federal legislation in different states, permitted the Hays Office to actually enforce the Production Code.

On July 1, 1934, Joseph I. Breen was placed at the head of the Production Code Administration, the PCA. From that moment, it was agreed that no company belonging to the MPPDA would distribute or release or exhibit any picture, unless it had received a certificate of approval signed by the director of the Production Code Administration and bearing the PCA's seal.

\section{The Hays Office after 1934}

So the year 1934 brought about the instalment of a rigid apparatus of auto-censorship, which would regulate film production from the 1930's until 1968, and this, according to some, in a Draconian way (Cook, p. 229). The concrete workings of The Hays Office have been well described in several publications. One of the first, albeit somewhat partial descriptions can be found in the contemporary study by Raymond Moley, called The Hays Office. First, a preliminary conference was organised between Breen or other members of the staff and the producer, for a consideration of the basic story. This conference was held even before the screen adaptation was written. Sometimes, a conference even preceded the purchase of the source material. Subsequently, a script submitted by the producing company was carefully scrutinised by staff members, who reported to Breen any violation of Code requirements. Throughout the preproduction phase, screenplay conferences were organised with the writers and other collaborators of the crew, during which eventually, changes were effected. Before passing on to the production phase, the producer had to obtain a written approval of the screenplay. Conferences also continued during production, so that any changes made in the script as well as all lyrics, costumes and sets, may be observed and passed upon. Often, the PCA recommended that the producer make so-called "protection shots" of particular scenes. Protection shots were to avoid the expense of possible retakes, in the event that the original se- 
quence should prove to be offensive when seen in its context. Protection shots were also recommended for scenes which may not be acceptable in particular countries. For example, scenes portraying a surgical operation were banned in Great Britain. The protection shots which the PCA would recommend for use in England would contain the dialogue and story points of the original operating-room scene, but would be photographed in the corridor of the hospital or in some other location acceptable to the English censors. When the picture was completed, a preview was organised in the projection room of the PCA. If any violation of the Production Code was detected, deletion of scenes, dialogues and/or actions had to be made. If not, a certificate of approval was issued, permitting the picture to be distributed and exhibited by an MPPDA member company or its affiliate.

\section{The production code and film noir adaptation}

The Production Code clearly offers a set of normative norms, prescribing what could be filmed and what could not. An interesting question in the field of descriptive film adaptation studies is therefore: how and to what extent has the Production Code determined the production process of film adaptations? How and to what extent have the normative norms succeeded in becoming operational, that is descriptive adaptation norms?

\section{The film noir corpus}

In the aforementioned study on the American film noir of the 1940 's and 1950's, I have tried to find some answers to these questions. The study dealt with a concrete corpus of thirty films noirs. For practical purposes, I have limited my scope to a comparison of the filmic and literary stories. Such a limited comparison has nevertheless led to some interesting observations: 1 . the Production Code and the literary model conflicted with each other on several points; and 2. even though the Production Code determined largely film production after 1934, filmmakers have continued to find compromises between the regulations of the Production Code and the literary model. Before going into these observations, however, I first repeat the list of films 
and novels that were examined. As I stated earlier, this corpus served as a working field for the study of several adaptation norms (Cattrysse, 1992).

Films

1941 The Maltese Falcon(WB) ${ }^{2}$ Suspicion (RKO)

1942 Street of Chance $(\mathrm{P})$

This Gun for Hire (P)

1944 Christmas Holiday $(\mathrm{U})$

Double Indemnity $(\mathrm{P})$

Laura (TCF)

Murder, My Sweet (RKO)

Phantom Lady (U)

1945 Confidential Agent (WB)

Hangover Square (TCF)

Mildred Pierce (WB)

Ministry of Fear (P)

1946 The Big Sleep (WB)

Black Angel (U)

Deadline at Dawn (RKO)

Dragonwyck (TCF)

The Postman Always Rings

Twice (MGM)

1947 The Brasher Doubloon (TCF)

Dark Passage (WB)

Lady in the Lake (MGM)

1947 Out of the Past (RKO)

Ride the Pink Horse (UI)

1948 The Big Clock (P)

The Lady from Shanghai (C)

The Pitfall (UA)

1950 In a Lonely Place (C)

1952 On Dangerous Ground (RKO)
Novels

1930 id. (Dashiell Hammett)

1932 Before the Fact (Francis Iles)

1941 The Black Curtain

(Cornell Woolrich)

1936 id. (Graham Greene)

1939 id. (William Somerset

Maugham)

1936 id. (James M. Cain)

1942 id. (Vera Caspary)

1940 Farewell My Lovely

(Raymond Chandler)

1942 id. (Cornell Woolrich)

1939 id. (Graham Greene)

1941 id. (Patrick Hamilton)

1941 id. (James M. Cain)

1943 The Ministry of Fear

(Graham Greene)

1939 id. (Raymond Chandler)

1943 The Black Angel

(Cornell Woolrich)

1944 id. (Cornell Woolrich)

1943 id. (Anya Seton)

1934 id. (James M. Cain)

1942 The High Window (Raymond Chandler)

1946 id. (David Goodis)

1943 The Lady in the Lake (Raymond Chandler)

1946 Build My Gallows High

(Daniel Mainwaring)

1946 id. (Dorothy B. Hughes)

1946 id. (Kenneth Fearing)

1938 IfI Die Before I Wake (Sherwood King)

1947 The Pitfall (Jay Dratler)

1947 id. (Dorothy B. Hughes)

1945 Mad with Much Heart

(Gerald Butler) 

Sudden Fear (RKO)
1953 The Big Heat (C)
id. (Edna Sherry)
1951 id. (William P. McGivern)

\section{The Production Code and the film noir adaptations}

The Production Code was divided in two sections: a short section dealing with general principles, and a longer one containing particular applications. The first part of the Code was short and contained three elements, which were very general indeed :

1. No picture shall be produced which will lower the moral standards of those who see it. Hence the sympathy of the audience shall never be thrown to the side of crime, wrong doing, evil or sin.

2. Correct standard of life, subject only to the requirements of drama and entertainment, shall be presented.

3. Law, natural or human, shall not be ridiculed, nor shall sympathy be created for its violation. (quoted in Moley, p. 98-99)

The section of the "Particular applications" comprised several subdivisions: crimes against the law, sex, vulgarity, obscenity, profanity, a subdivision called "costume", dances, religion, locations and national feelings. In the following, I select some Production Code regulations and confront them with the adaptational behaviour of the film noir corpus, in order to find out if and how filmmakers have chosen between the Production Code and the literary model they tried to adapt to the screen.

\section{1 A clear-cut distinction between good and evil}

One of the main objectives of the Code consisted in making pictures that did not lower the moral standards of those who saw them. Moral standards were lowered:

a) When evil is made to appear attractive and good is made to appear unattractive;

b) When the sympathy of the audience is thrown on the side of crime, wrong doing, evil, sin [...]. (quoted in Moley, p. 99) 
The Production Code wished that a clear-cut distinction be made between good and evil, and this throughout the presentation.

In elaborating on the question of sin and sympathy, the Code says, in effect, that evil, even though later punished, must not be made so attractive that in the end the condemnation will be forgotten and only the apparent joy of the sin will be remembered; and that, therefore, evil and good are never to be confused "throughout the presentation." (Moley, p. 100)

Throughout the presentation, it was important to show that sin was not an accidental error, but a shameful breach of the law; that evil was not pleasant but painful, not heroic but cowardly, not profitable but destructive. The Code wanted onedimensional characters, good guys and bad guys. Stories had to make clear that in the end, the good guy won, and the bad guy lost and was severely punished. This general principle went clearly against the norm some writers of popular crime literature had set up. They wanted to break with the traditional blackand-white description of heroes and foes. They wanted to tell ambiguous stories with ambivalent characters in dubious settings. As James M. Cain called it in his For Men Only, they wanted to do away with "our national curse (of) the sympathetic character." These writers wanted to disturb the old social and political certainties and show how violence, sex and corruption had invaded the American society into its highest regions.

In the film noir corpus, one notices that the filmmakers have evidently been forced to moderate the innovatory literary characteristics by diminishing the criminal and ambivalent aspect of certain characters. ${ }^{3}$ These modifications are especially obvious in the criminal stories told from the point of view of the criminal. The adaptations of Double Indemnity and The Postman Always Rings Twice offer two striking examples of applications of the Code in this respect. As soon as Nick has been killed in the movie The Postman Always Rings Twice, the main characters do not live one single moment of happiness. In the novel, however, Frank's relation with Cora has its ups and downs, even after Nick's death. They get married in a romantic atmosphere. Some- 
times, they quarrel, but generally they end up getting drunk and making up to each other. On the other hand, the film adaptation stresses the mutual and continuous suspicion between the two characters. At the end, it is even suggested that Cora believes Frank causes the accident on purpose, to get rid of her. In an analogous way, the charm of the relation between Walter Neff and Phyllis Dietrichson is broken after the murder of Mr. Dietrichson in the film adaptation of James Cain's Double Indemnity.

Another rule which is closely linked to the black-and-white description of values states that the good guy should never resort to murder, not even in self-defence. When this happens in the novel, the film adaptation generally transfers the murder to another less important character who kills the criminal in a final shoot out. This occurs for example in the final scene of Laura. In the novel, police detective Mark McPherson kills the murderer, Waldo Lydecker, in circumstances which are morally ambivalent, to say the least. In the film adaptation, McPherson has his hands full holding Laura, and it is a colleague of his who kills Lydecker in self-defence.

The clear-cut distinction between good and evil overlaps of course partially the presentation of violence. I will hereafter explain that in matters of violence, the Production Code was not always as rigourous, and that as a consequence, adaptational behaviour is not always consistent. This explains probably in part why exceptions were tolerated with respect to the use of violence of the main character. For example, in the film adaptation of The Big Sleep, Philip Marlowe lures bad guy Canino in a trap and shoots him dead. Actually, this is the first and only movie where Marlowe kills someone. Even Chandler received much criticism in his time from his readers. Another exception can be found in the film adaptation of David Goodis' Dark Passage. Here, Vincent Parry is accused of having murdered his wife. Parry did not kill his wife, but he murders two persons in the novel. Contrary to the other films noirs of the corpus, the adaptation does not delete these two killings, and contrary to the Production Code, Parry is not killed nor punished at the end of the movie. These exceptions show that, from time to time, filmmakers succeeded in escaping the rules of the Production Code, 


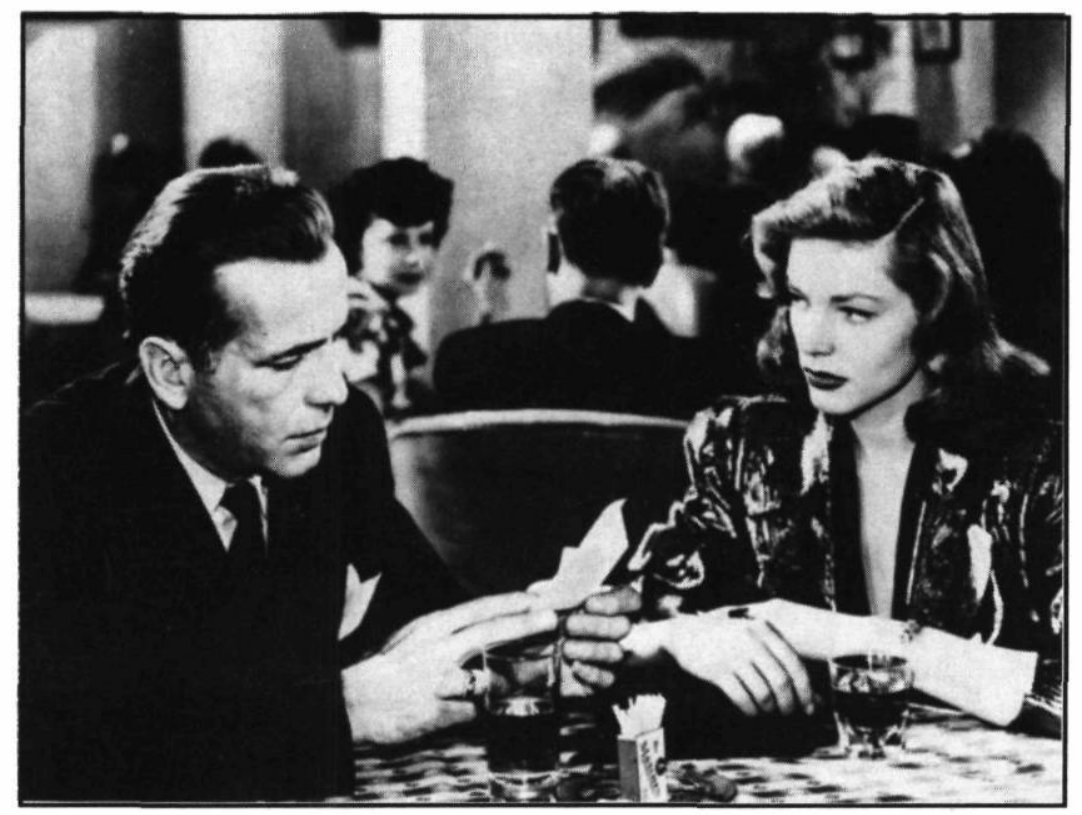

The Big Sleep, H. Hawks (1 946)

Collection Cinémathèque québécoise

and they managed to import effectively characteristics of the literary model into the filmic practice. In this case, they represent as many symptoms of the subversion of the myth of the sympathetic character.

\section{2 The compensating moral values}

The Code demanded that " $[\ldots]$ in the end the audience feels that evil is wrong and good is right." (Moley, p. 101) This meant first of all that under no circumstances, the bad guys could come out winning over the good guys. In the attempt to attack the myth of the sympathetic character, some writers went as far as to let the evildoers go free at the end of the story. This could not be tolerated of course by the Production Code. An example can be found in the film adaptation of Build My Gallows High. In the novel, the main criminals, Mumsie McGonigle and Guy Parker, come out alive and winning, whereas in the adaptation, they are killed. Another example can be found in the adaptation of Mildred Pierce. ( $c f$. infra) 
To meet the requirements of the Code, film adaptations had to introduce "compensating moral values." This means that stories had to contain sufficient good to compensate any evil that was related. Compensating moral values were: good characters, the voice of morality, a lesson, regeneration of a transgressor, suffering and punishment.

Many shifts in the film noir corpus seem to find their origin in this norm. The addition of a "good" character and / or the increase of its importance, as a reply to the requirement of compensating moral values, seems to occur mostly in stories presenting a fermme fatale. Faced with the couple of the femme fatale and her male victim, filmmakers add or augment the importance of a "normal" couple. As opposed to the couple that failed, they present the couple that succeeded, revalorising in this way the matrimonial bond. For example, in the movie Double Indemnity, the character of Lola becomes more important. She acts as a foil to the femme fatale Phyllis. In Murder, My Sweet, the expansion of the role of Ann Grayle helps to solve the amorous conflict between Marlowe and Helen Grayle ${ }^{4}$. The film adaptation of Hamilton's Hangover Square adds a character called Barbara. She is a highly respectable woman who wishes to marry George Harvey Bone and to establish a perfectly conventional household. And Out of the Past increases the importance of Jim Caldwell (Joe in the movie) and modifies the end of the story to join Jim and Ann in a happily married couple, and to counterbalance the destructive and suicidal couple of Jeff Bailey and Kathy Moffett.

In this type of stories, the shifts produced by the adaptation norm of the "love rack" correspond generally with a compensation of a failed relationship. In this sense, the films noirs present a world which is definitely less pessimistic than the novels they adapt to the screen.

\section{3 De-glamorisation}

The Code proclaimed that no crime may be presented as pleasant or profitable. In addition to the clear-cut presentation of good and evil and the compensating moral values, certain film noir adaptations present another transpositional device 
which I call the "de-glamorisation"s of the criminal. This technique consists in reducing the pleasant or profitable aspect of crime. Even though a character may not be presented in too appalling a way, the Code states that under no circumstances, a criminal may be shown as superior to honest people. For example, the character of Veda undergoes an important process of deglamorisation. In the novel, Veda sets up a blackmail business and receives a great deal of money, though the exact amount of money is never made explicit. In the movie, Veda receives a cheque for $\$ 10000$, but Mildred discovers the criminal project, tears up the cheque and Veda ends up without a cent. In the novel, Veda becomes a succesful opera singer, who produces a show at the Hollywood Bowl and appears on the radio. At the end of the novel, her ultimate victory consists in a new contract which leads her to stardom in New York. In the film adaptation, however, Veda sings in a shabby bar to earn a living after she broke off with Mildred. Nobody could ever have made the Veda of the novel sing in a seedy-looking bar like Wally Fay's in the movie. And at the end of the movie, Veda does not triumph; instead, she is convicted for the murder of Monte Beragon, her mothers second husband. Whereas the novel tells the story of a criminal who comes out winning, the film adaptation turns the novel into story where the forces of good win over the forces of evil: matrimony is revalued as an institution, and woman is restored into her "proper" place... The film adaptation of Dragonwyck offers another illustration of the process of "de-glamorisation." The novel presents a character by the name of Nicholas Van Ryn. Van Ryn is not only discontented by life and by the impossibilitity of producing a son and heir of his estate and his feudal system, he is also a superior human being, intellectually as well as physically, and he is very disappointed by the mediocrity that surrounds him. Consequently, the movie character, which is performed by Vincent Price, is transformed into a weakling, who is himself very mediocre and even mentally disturbed.

\section{4 The presentation of violence}

The Production Code was not always specific on the subject of violence. On some points, it was less strict, on others it was 
categorical. This attitude is reflected in the adaptation behaviour of the film noir corpus. For example, the Code was very specific concerning certain forms of violence. Some subjects were taboo, such as hangings, electrocutions, and other forms of legal punishment for crime. In this respect, the deletion of the famous, final execution scene in the gas chamber, in Double Indemnity, is illustrative.

Other subjects not to be displayed were third degree methods, brutality and gruesomeness, branding of people or animals, apparent cruelty to children and animals, surgical operations (cf. supra), and so forth. But as the novels seem to have undergone also a process of auto-censorship on these points, these subjects do not lead to any significant shifts in the film noir adaptations.

There was also a ban on showing (techniques of crime in such a way as to inspire viewers with a desire for imitation. In a precedent article (Cattrysse 1992a), I mention "transfocalisations" ${ }^{6}$ which shift the narrative point of view to show a murder or a suicide. However, these murders or suicides, which generally happen by means of a revolver, never involve the presentation of blood or injuries. What is more, even though in general the movies have respected the Production Code with reference to the presentation of (techniques of) crime, most novels are also discrete in describing this kind of material.

Although the Code was not always as specific, one can conclude, at least for the film noir corpus, that in general, shifts on the level of violence tend to diminish the amount of violence, not to increase it. For example, the novel The Maltese Falcon presents some very sadistic scenes where Gutman tortures his daughter. These scenes are deleted in the movie. Removing seventy-five percent of the story from the novel, the film adaptation of The Black Angel cuts at the same time an important amount of violence from the novel. The end of Street of Chance is less violent than the end in The Black Curtain. One has only to remember the scene where Bill carves himself with a knife to convince the police that he has killed Frank Townsend in selfdefence. The adaptation of Mildred Pierce deletes the scene where Mildred tries to strangle her daughter Veda. Finally, the adaptation of The Postman Always Rings Twice also moderates 
the violence of the novel. Think of the brutal beating of Kennedy by Frank in the novel, which is pictured in a more delicate way. The film noir corpus presents one exception though which increases the amount of violence present in the novel. An explanation for this exception may lie in an adaptation technique called "periodisation."

\title{
2. 5 The periodisation
}

The Hays Office recognised that crime is a legitimate subject for dramatic presentation. With reference to the presentation of violence, Joseph I. Breen pointed out that the interpretation of the Production Code could be adapted if the story played in another time or another culture :

\begin{abstract}
Law and order cannot be expected to prevail in the historic Wild West. It is evident, furthermore, that Shakespeare and Eugene O'Neill cannot be judged exactly alike. Again, the evil usages of a bygone age, no longer practised, are not subject to the same critical examination as modern ways and customs. In general, historic and older classical subjects possess a certain quality of distance and unreality which mitigates effects that would be evil in a similar modern subject. (quoted in Moley, p. 100)
\end{abstract}

An adaptation technique which could provide greater tolerance towards violence was therefore the "periodisation." The technique consists in transferring the story back in time. It is, however, hardly applied in the film noir corpus. Most films noirs tell contemporary stories, and those films which present a story in the past, are mostly based on a literary story which was already situated in the past. There is one exception though, which is interesting here because it presents a combination of a "periodisation" with an increase of amount of violence. The exception is Twentieth Century-Fox's film adaptation of Patrick Hamilton's Hangover Square. The novel tells the story of a schizophrenic drunk, George Harvey Bone, who lives in London in the 1930's. At irregular intervals, George suffers from attacks of alcoholic amnesia. During these attacks, he becomes a different person who prepares and finally executes the murder of 
a bitch called Netta. The movie transposes Hamilton's story back into the early 1900's, in London at the time of Jack the Ripper. It suppresses any link with alcoholism and thus eliminates the metaphorical meaning of the title. In the movie, Hangover Square refers to a respectable square where the prestigious composer George Harvey Bone lives. Since motion pictures represent an audio-visual medium, George's illness is concretised in an audio-visual way: it is associated with the abrupt eruptions of sounds which start schizophrenic attacks. He then becomes also a different person, which begins to murder without a reason, and without remembering anything afterwards. However, unlike the other films of the corpus, Hangover Square increases the amount of violence present in the novel. It adds a second murder and one murder attempt to the one murder of Netta in the novel. Having read the regulation of the Production Code, one can suppose that the filmic "periodisation" of the literary story has helped the filmmakers to pass the increased amount of violence through the Hays Office. Furthermore, the film adaptation offers an interesting and rather exceptional transfer on the level of genre. With the "periodisation" of Hamilton's novel, the movie tells a gothic story. The fact that John Brahm made the film after having successfully directed The Lodger (1944) the year before, represents probably no coincidence. This genre transfer may also have contributed to make the increased violence of the film story more acceptable.

\section{6 Drugs and alcohol}

The subdivision of the crimes against the law contains also a heading dealing with the use of drugs and alcohol. The attitude towards the use of drugs is not always very clear though : any direct or indirect allusion is prohibited. The subject appears only twice in the corpus. In the novel Phantom Lady, Cliff Milburn smokes a couple of marijuana cigarettes, and in the novel Black Angel, Alberta sells drugs to Dr. Mordaunt. These actions are deleted in the respective film adaptations.

The Code was more lenient towards the use of alcohol: "The use of liquor in American life, when not required by the plot or for proper characterisation, will not be shown." (Moley, p. 103) 
The attitude of the filmmakers is therefore more ambivalent too. For example, Paramount's adaptation of Charles Jackson's novel The Lost Weekend (1945), which does not figure in the corpus, represents a clear case in point: alcoholism constitutes the main theme of the story, and thus it is maintained in the story of the adaptation. However, when alcoholism does not constitute the main theme of the story, the adaptation policy is less consistent. For example, the adaptation of The Black Angel deletes the scenes where Alberta drinks gin to get courage, but it changes Ladd Mason's attacks of epilepsy to a more plausible alcoholic amnesia of Martin Blair. On the one hand, the adaptation of Mildred Pierce increases the use of alcohol by Mildred, as a connotation for Mildred's entrance in a man's world. On the other hand, the adaptation of Before the Fact removes the scenes where Johnny serves alcohol to Lina each time they have a fight, and each time suspicion and anguish reach their peak.

\section{7 Sex}

This section represents a subject which has been regulated in quite a stricter manner. Shifts are all the more clear in the film noir corpus since the novels have undergone a much looser regime of censorship in this respect. The section is subdivided in several headings, which precise different prohibitions such as adultery, scenes of passion, seduction, rape, all sorts of perverted sexuality, white slavery, miscegenation (sex relationship between the white and black races), man and woman in bed together, sex hygiene and venereal diseases, scenes of actual childbirth - in fact or in silhouette - children's sex organs, etc. Several of these subjects are dealt with in passing in a number of novels. Generally, the Production Code has deleted these passages from the adaptation, although not all topics are regulated with the same strictness. For example, adultery was regulated less strictly: "Adultery, sometimes necessary plot material, must not be explicitly treated, or justified, or presented attractively." (Moley, p. 106)

The film noir adaptations behave consequently. The theme of adultery occurs in at least fifteen novels: The Maltese Falcon, Before the Fact, The Black Curtain, Double Indemnity, Farewell, 
My Lovely, Phantom Lady, Mildred Pierce, The Big Sleep, Black Angel, The Postman Always Rings Twice, The Lady in the Lake, The Big Clock, If I Die Before I Wake, The Pitfall, and Sudden Fear. If the theme is explicitly present without being necessary to the rest of the story, the film adaptation "corrects" the novel and deletes the adultery theme or diminishes its importance. For example, in Before the Fact, adultery constitutes one of Johnny's many defaults. Therefore, it is removed from the story. In the same way, the adultery of Frank in The Black Curtain and of Alberta in The Black Angel are deleted in the respective film adaptations. In Phantom Lady, the love affair between Scott Henderson and his secretary Kansas is postponed until after the death of the wife. The adaptation of Mildred Pierce deletes Mildred's sexual promiscuity. In the novel, Mildred uses her sexappeal to obtain favours from several men: she jumps in bed with Wally and Monte, and she flirts with Mister Otis, the butcher, because he can get her a interesting loan for her restaurant. The movie removes all these disputable actions from the story. In fact, only the adaptation of The Maltese Falcon maintains the adulterous relationship between Sam Spade and his partner's wife, even though it is not essential to the rest of the story.

In other film noir adaptations, the adulterous relationship is maintained because it is essential to the rest of the story. Examples here are Double Indemnity, Farewell, My Lovely, The Big Sleep, The Postman Always Rings Twice, The Lady in the Lake, The Big Clock, If I Die Before I Wake, The Pitfall, and Sudden Fear.

The somewhat less univocal attitude towards adultery interferes however with one regulation which is defined in a much more strict way, and which states that under no circumstances, the institution of marriage may be displayed in a unfavourable light. As a consequence, no film adaptation makes an exception to this rule. Only The Piffall goes a little further in describing the monotony of the matrimonial relationship between John Forbes and his wife Sue; monotony which is actually stressed more strongly in the movie than in the novel, and which causes the adulterous relationship of Forbes with the femme fatale Mona. 
Moley adds several paragraphs describing "improper" forms of love. (p.106ff.) These paragraphs apply especially to the adaptations of James Cain's novels. Thus the necrophiliac character of Phyllis is removed from the novel Double Indemnity, the bestial desire of Frank for Cora is deleted in the adaptation of The Postman Always Rings Twice, and the unnatural love of Mildred for Veda is "normalised" in the movie. At a certain moment, the screenplay presents a line concerning Mildreds love for Veda saying: "It isn't natural." The movie changes this line into "it isn't right." (La Valley, p. 241)

The Production Code also stipulates that natural children do not exist. Accordingly, film adaptations eliminate them from their stories. For example, the film adaptation Suspicion removes the natural child Johnny Aysgarth has with the maid in Before the Fact.

Homosexuality and incest are also banned subjects. No novel deals with the subject of incest, and, hence, no shifts appear in this respect. Although the theme of homosexuality occurs repeatedly in the novels, filmmakers have largely eliminated it in their film noir adaptations. For example, the adaptation of Caspary's novel Laura eliminates the masochistic and homosexual nature (especially present in the chapter narrated by Waldo Lydecker) of the relationship between Mark McPherson and Waldo Lydecker. Although most references to homosexuality have been removed, some film adaptations maintain homosexual insinuations here and there. Think of the ambiguous relationship between Gutman, Wilmer and Cairo in The Maltese Falcon, or between Geiger and Lundgren in The Big Sleep. The adaptation of The Big Clock also maintains the allusion to Earl Janoths homosexuality.

Finally, illicit sex and prostitution are equally banned subjects. Accordingly, the character of Lydia, which is a prostitute in Somerset Maugham's Christmas Holiday, becomes a hostess in a bar. Similar characters in Phantom Lady and Black Angel are "neutralised" in an analogous way.

\section{8 Vulgarity, obscenity, profanity, costume, ...}

The "Particular applications" of the Production Code refer also to topics such as vulgarity, obscenity, profanity, costume, 
etc. Apparently, the norms that determined the writers coincided largely with those that guided the filmmakers in this respect. The concepts and headings also overlap partially. Profanity refers to a list of hundred words and expressions " [...] whose suggestiveness and offensiveness is scarcely open to debate." (Moley, 1945, p. 109) It includes words like God, Lord, Jesus, Christ, unless used reverently, Hell, S. O. B., Damn, Gawd, etc. Comparing the language of the movies with the language of the novels on the level of profanity, I did not observe any significant changes.

The heading called "costume" refers largely to the absence of it, that is to nudity. Here, the literary norms differ clearly from the filmic ones. Whereas some novels present nude scenes, nudity is unconditionally forbidden, and not a single nude scene is maintained in the film noir adaptations. For example, in Hammett's The Maltese Falcon, there is a scene where Brigid has to strip off to prove that she did not steal the Spade's money. This scene is evidently removed from the film. For the same reason, the adaptation of The Big Sleep deletes several scenes from the novel : for example, the scene where Carmen sits naked in Geigers living room to let him take pictures of her, and subsequently, the scene where she is in bed, covered only by a sheet, waiting for Marlowe to come home. Other nude scenes are eliminated in the adaptations of The Black Curtain, Christmas Holiday, Mildred Pierce, The Postman Always Rings Twice, and The Pitfall.

There is no need to explain that in some cases, the deletion or modification of the nude scene complicates a good understanding of the scene. For example, in the aforementioned scene of The Big Sleep, it is, to say the least, a little strange, to see Carmen completely dressed before a camera, and to believe that pictures have been taken to blackmail her.

A subdivision that is linked with the sex section concerns the treatment of locations. These locations do not concern only sordid bars and brothels, there is also a special mention about bedrooms: "The treatment of bedrooms must be governed by good taste and delicacy." (quoted in Moley, 1945, p. 110).

Moley mentions the case of the adaptation of Tolstoy's Anna Karenina, where Breen informed the producer that no scene 
should play in Anna's bedroom. Bedroom actions had to be transferred into her boudoir, or, if possible, into her living room. In an analogous way, several scenes from The Postman $\mathrm{Al}$ ways Rings Twice are transferred from the bedroom to other locations, even when they contain absolutely "innocent" actions.

A final point of censorship concerns the deletion of sociopolitical subjects. The elimination of scenes containing criminal and sexual actions imply also interventions which are of a sociopolitical nature. I limit the examples hereafter to some propagandistic uses of literary and filmic texts. With reference to this, Breen notes that: "To teach and to preach are not the primary functions of the motion picture. [...] In passing judgment upon stories, the idea of entertainment has to be constantly kept in mind." (quoted in Moley, p. 98)

From this follows that even in a corpus of popular literary texts, many shifts are to be explained by the deletion of sociopolitical elements which were considered too persuasive and too committed. The novel Before the Fact contains several reflections on differences between social classes, which are deleted in the film adaptation. The left-wing sympathies of McPherson are also eliminated in the adaptation of Laura, and the theme of political corruption is neutralised in the adaptation of Ride the Pink Horse, since the character of senator Douglas is transformed into an ordinary gangster.

Although most novels do not present passages which may offend on a racist plane, the novel Farewell My Lovely offers a striking example of racist treatment of blacks. The film adaptation deletes these racist passages. Due to this kind of deletions, the film noir adaptations generally tell a story which is politically and socially less subversive than the story of the novel. It must be said, however, that in a popular literary genre such as the "roman noir," political or social statements are hardly predominant.

\section{Conclusions}

Since the films noirs of the corpus were produced in the 1940 's and the 1950's, a high influence of the Hays Office on film adaptation was to be expected. On many points, filmmak- 
ers have therefore been obliged to meet the Production Code requirements, and normative norms have functioned effectively as descriptive production and adaptation norms. A clear case in point are the regulations dealing with the representation of nudity and sex. The exceptions to the rule represent often points where the literary model has managed to overrule the Production Code. Here, the normative norms have remained normative, and a different descriptive norm has determined the filmic practice. A striking example in this respect dealt with the blackand-white representation of good and evil. As I stated before, filmmakers have been forced to moderate the innovatory characteristics of the novels they adapted, but compared to the classical Hollywood cinema of the 1930's, the American film noir has often been noticed, by contemporary audiences as well as by critics later on, for its morally ambivalent characteristics. Compared to the adapted literature, the filmmakers have set a step back on the level of the sympathetic character, due to the Hays Office. In comparison with the previous film practice, however, the film noir adaptations have set a step forward, due to the literary model they adapted to the screen.

This brief comparison of the Production Code with the adaptation practice shows also that subjects which were regulated more strictly (e.g. questions dealing with sex) correspond with a meticulous adaptation behaviour, whereas subjects which were regulated more loosely (e.g. alcoholism or homosexuality) correspond with a more ambiguous transformational practice.

Finally, this short comparative analysis demonstrates that normative norms should not be confused with descriptive norms, and that a study of the former can contribute to a better understanding of the functioning of the latter.

Katholieke Universiteit Brussel

\section{NOTES}

1 A more detailed description of the poly-system method with some results can be found in Patrick Cattrysse "Pour une approche intersystémique du cinéma", in Jürgen E. Müller (editor), Towards a Pragmatics of the Audiovisual (Münster: Nodus Publikationen, 1994a, p. 61-75). 
2 The abbreviations stand for Warner Brothers (WB), Twentieth Century-Fox (TCF), Paramount (P), Universal (U), Universal-International (UI), United Artists (UA) and Columbia (C).

3 The moral shifts do not occur, of course, in an isolated manner. In Pour une théorie de l'adaptation filmique. Le film noir américain (Bern: Peter Lang, 1992b), I describe several adaptation norms, e.g. on the level of genre and empathy. These shifts seem to be related also to the moral norms, imposed by the Hays Office.

4 This shift is also linked with the adaptation norm of the "love rack." See Patrick Cattrysse, Pour une theorie de l'adaptation. Le film noir américain (Bern: Peter Lang, 1992 b, p. $152 \mathrm{ff}$ ).

5 The term "glamorisation" appears already in Asheim studies, From Book to Film (Chicago: University of Chicago, 1949) and "From Book to Film: 'Mass Appeals", Hollywood Quartely, vol. 5 (1951), p. 334-349. See also Patrick Cattrysse, Pour une théorie de l'adaptation. Le film noir américain (Bern : Peter Lang, 1992b, p. 155 ff).

6 The term "transfocalisations" refers to a shift on the level of point of view. Instead of showing a scene from one perspective, it is shown from a different point of view. "Transfocalisation" often occurs to create suspense.

\section{WORKS CITED}

Asheim, Lester. From Book to Film (Ph. D. thesis). Chicago: University of Chicago, 1949.

Asheim, Lester. “From Book to Film: 'Mass Appeals'”. Hollywood Quarterly, vol. 5 (1951) p. 334-349.

Cattrysse, Patrick. "Film (adaptation) as translation: some Methodological Proposals". Target. International Journal of Translation Studies, vol. 4, n 1 (1992a) p. 53-70. Cattrysse, Patrick. Pour une théorie de l'adaptation filmique. Le film noir américain. Bern : Peter Lang, $1992 \mathrm{~b}$.

Cattrysse, Patrick. "Pour une approche intersystémique du cinéma," in Jürgen E. Müller (editor), Towards a Pragmatics of the Audiovisual. Münster: Nodus Publikationen (1994a) p. 61-75.

Cattrysse, Patrick. "The Study of Film Adaptation: a State of the Art and Some 'New' Functional Proposals", in Eguiluz, Federico and Raquel Merino (eds.), Transvases Culturales: Literatura, Cine, Traducción. Vitoria: Universidad del Pais Vasco (1994), p. 37-56.

Cook, David A. A History of Narrative Film. London: W.W. Norton \& Co, 1990.

La Valley, Albert (ed.). Mildred Pierce. Wisconsin / Madison: The University of Wisconsin Press, 1980.

Leff, Leonard J. and Jerol L. Simmons. The Dame in the Kimono. Hollywood, Censorship of the Production Code from the 1920's to the 1960's. New York: Grove Weidenfeld, 1990.

Moley, Raymond. The Hays Office. New York: The Bobbs-Merrill Company Publishers, 1945. 